\title{
The Relationship Between Quality Management Practices and Productivity in Revenue and Cost Management : A Study of Local Authorities in Peninsular Malaysia
}

\author{
KHAIRUL ANUAR MOHD. ALI \\ Faculty Science and Technology \\ Universiti Kebangsaan Malaysia \\ RUSHAMI ZIEN YUSOFF \\ ZAKARIA ABAS \\ Quality Management Institute \\ Universiti Utara Malaysia
}

$(1$

ABSTRACT

The globalization and liberalization of the world economic system have brought us to an era where global competition is highly intense. The introduction of new technology and systems has greatly affected the performance of organizations. Quality is widely recognized as one of the important disciplines and strategies for competitiveness. This study examines the relationship between quality management practices and the productivity in revenue and cost management in local authorities. Three hundred twenty managers from eighty organizations participated in this study. Disproportionate stratified random sampling was used as the sampling technique from the population frame and the data were gathered through self-administered structured questionnaires. The results of the regression analysis showed that only two constructs among the seven quality management practices were found to be significantly related to productivity in revenue and cost management. The construct for employee focus has a positive association with the productivity in revenue and cost management whereas process - management has a significant inverse relationship with the productivity in revenueand cost management. Thus, local authorities need to address these two constructs in order to achieve a higher level of productivity in revenue and cost management.

Key words: quality, management practices, revenue, cost management, local authorities.

\section{ABSTRAK}

Globalisasi dan liberalisasi di dalam sistem ekonomi dunia telah membawa kepada satu era persaingan global yang sengit. Kemunculan sistem dan teknologi baru telah banyak mempengaruhi prestasi organisasi. Kualiti telah dikenal pasti sebagai salah satu daripada disiplin utama dan penting di dalam 
strategipersaingan. Kajian inimeneliti hubungan antara amalan pengurusan kualitidengan produktiviti dalam penjanaan hasil dan pengurusan kos di kalangan Pihak Berkuasa Tempatan Semanjung Malaysia. Tiga ratus dua puluh pengarah daripada lapan puluh organisasi Pihak Berkuasa Tempatan telah terlibat dalam kajian ini. Pensampelan rawak berstrata tidak berkadaran telah digunakan dan data dikumpulkan melalui temu duga berstruktur dengan bantuan soal selidik. Hasil analisis regresi menunjukkan hanya dua konstruk daripada tujuh konstruk amalan pengurusan kualiti mempunyai hubungan dengan produktiviti dalam penjanaan hasil dan pengurusan kos. Konstruk untuk fokus terhadap pekerja mempunyai hubungan yang positif dengan produktiviti dalam penjanaan hasil dan pengurusan kos. Sementara pengurusan proses mempunyai hubungan yang negatif dengan produktiviti dalam penjanaan hasil dan pengurusan kos. Justeru itu, pihakberkuasa tempatan perlu mengambil kira kedua-dua konstruk tersebut bagi mencapai produktiviti yang lebih baik di dalam penjanaan hasil dan pengurusan kos mereka.

Kata kunci: kualiti, amalan pengurusan, penjanaan hasil, pengurusan kos, Pihak Berkusa Tempatan.

\section{INTRODUCTION}

The globalization and liberalization of the world economic system have brought us to an era where global competition is highly intense. The introduction of new technology and systems has greatly affected the performance of organizations. Quality is widely recognized as one of the important disciplines and strategies for competitiveness. The Local Governments, being service providers to the public, should not be immune to the pressure that drives an organization to be successful with quality services that satisfy the customers and stakeholders. According to Randall and Senior (1994), public sector services are experiencing pressures as a result of financial constraints, legislative changes, criticism of standards and political tension. Together with internal pressure, the desire for improved quality of service has become a major concern in the era of global competition. Thus, quality has become the important force leading to organizational success in national and international markets (Feigenbaum, 1991).
There are two types of customers of public services such as in local governments according to Donelly et al. (1995). They are the recipients or users of services who make either little or no financial contributions towards their provision; or those who have to pay for a particular public service but do not experience its benefit through direct use. Whoever their customers are, service quality initiatives in the local authorities need to focus and contribute to social good as well as discharge public accountability.

In Malaysia, there are a total of 145 local authorities (Ministry of Housing and Local Government, 2000). There is a total of ninetynine local authorities in West Malaysia and forty-six in East Malaysia. Since local authorities are very much involved in the development of a district, they have become one of the most important agencies in terms of development of the local districts. Hence, their efficiency and effectiveness of resource utilization that is being funded through budget allocation will greatly affect the economic growth 
of the country at the macro level. The efficiency and effectiveness of resource utilization is determined by their productivity in revenue and cost management. Having noted this, this study investigates the relationship between quality management practices and productivity in revenue and cost management among local authorities in West Malaysia

The rest of the paper is organized as follows: the background of the study and the research model are presented in the following section, followed by research methodology. The fourth section provides the results and (1) analyses. The implication and conclusion of - the study are presented in the fifth section and the final section respectively.

\section{BACKGROUND OF THE STUDY}

Quality products and services can be deliv- ered best when all of the organization's systems are efficient, effective and focused on the same target (Beechner and Koch, 1997). However, when there is a collection of 'ad hoc' systems by piecemeal approach of system development, efficiency and effectiveness is at stake; misconceptions and confusion often occur. Thus, establishment and maintenance of a total system approach is required, which in turn will best eliminate potential confusion and sub-optimization from the outset (Beechner and Koch, 1997). Given that, there is a growing recognition in the business world that old management approaches are no longer appropriate or effective. The sum of the common beliefs held by a majority of managers today comprises what is called the traditional management paradigm. Paradigm shifts, when the old paradigm nolonger works
(Raynor, 1992). Among others, is the development of an integrated approach to management, that is, Total Quality Management (TQM).

Owing to significant shifts in competitive edge, the need for continuous improvement and breakthrough on quality management practices are immense. The initiatives of employing quality methodologies in the form of strategic quality management or TQM and implementing quality assurance practices are therefore crucial.

Quality must be viewed as a moving target. Higher and higher performance standards must be set for everyone in an organization to provide a sense of working towards common goals. Consistent and committed top management leadership is the catalyst for moving the organizational culture towards espirit de corp in which all individuals, regardless of rank or position, are obliged to discharge their accountability. Such an attitude should permeate everything an organization does including supplier relation, marketing, research and development, product design, as well as information processing. Management can effectively induce change in its organizational quality practices by providing a conducive environment in which employees know that the organization cares and is responsive to their needs and will appreciate and rewards excellence. This knowledge goes a long way towards making the employees feel trusted, respected and comfortable. Such employees are more likely to treat customers in a similar manner.

An organization must empower employees to participate fully in the quest for excellence in quality by providing the means by 
which employees gain pride, satisfaction, and substantive involvement. Encouragement,job enrichment, training, and proper working environment and tools are what managers must provide. Employees should be recognized with praise and reward for their effective involvement in group problem solving, contributing of ideas for improvement, acting as monitors of their own work, and sharing their knowledge and enthusiastic attitudes with their colleagues.

There are many studies conducted towards gaining an understanding of quality programs and practices employed by organizations that are aimed at improving organizational performance and gaining competitive superiority in global market place. In this respect, Saraph et al. (1989) and Flynn et al. (1994) have proposed empirically validated scales of measures for integrated quality management aimed at providing better understanding of quality management practices in relation to an organization's quality environment and quality performance. Researchers have used such measures to better understand quality management practices and to build theories and models that relate the critical factors of quality management to organizational performance.

Benefits from employing quality practices are documented well in quality literatures. Among others, Powell (1995) investigated the possibility of incorporating TQM practices to gain and sustain competitive advantage. Drawing on the resource approach, his study examined TQM as a potential source of sustainable competitiveness. He found organizations that put TQM practices in place outperform their competitors, among others, the findings suggested that financial performance was positively associated with quality management practices. Others have also indicated of the importance of customers satisfaction on financial performance (Kotler, 1994; Ronen and Pass, 1994; Garvin, 1984, 1988). Some have claimed that successful implementation of TQM could generate improved products and services, reduce costs, increase satisfied customers and employees, and improve financial performance (Walton, 1986; Garvin, $1983,1984,1988)$. In this respect, organizational performance is the function of quality management practices.

Given the benefits of successful implementation of quality management initiatives cited in the preceding paragraphs, this study investigates the phenomenon of quality management practices in relation with organizational performance in local authorities in West Malaysia. Seven prominent quality management practices are identified from literature. The seven variables are top management influence, customer focus, employee focus, quality training, supplier relationship, information and communication technology, and process management. Hence, the objective of this study is to identify the elements of quality management practices that perhaps may have significant bearing on the variability in the level of productivity in revenue and cost management as a proxy to organization performance. Thus, the model used in this study, which is expressed in the form of regression model is as follows:

$$
\begin{aligned}
P R C M= & a+b_{1} T M I+b_{2} C F+b_{3} E F+b_{4} Q T \\
& +b_{5} S R+b_{6} I C T+b_{7} P M+\varepsilon
\end{aligned}
$$




\section{METHODOLOGY}

\section{Study Design}

This study employed a field survey method and data were obtained from the head department of each local authority through self-administered personal interview aided by structured questionnaires. As this study goes beyond merely describing the variables in a situation to understand the relationships among factors of interest between the dependent variable (productivity in revenue and cost management) and independent variables (quality management prac(1) tices), the nature of investigation of this study - was correlational (analytical and predictive).

Variables of a study can neither be manipulated nor controlled, and no artificial setting was created for the study, therefore this study was conducted in a noncontrived setting. As the data for this study was collected at

"a single point in time (Sekaran, 2000), this study was a cross-sectional in time horizon.

\section{Sampling Frame}

The population of this study consists of all local authorities in West Malaysia. The list of local authorities was obtained from the Handbook of the Ministry of Housing and Local Government, Government of Malaysia Year 2000. According to the list, there are ninety-nine local authorities serving West Malaysia. All local authorities in West Malaysia were invited to participate in this study. However, only eighty organizations were willing to participate.

As a general rule, Roscoe (1975) as cited by Sekaran (2000), proposed that the appropriate sample size for most research should be larger than thirty and less than 500. While for the multivariate study, the sample size should be several times, preferably ten times or more, as large as the number of variables understudy. Thus, eighty organizations as sample to represent the population were sufficient, as well as meet the statistical requirement for the regression analysis.

\section{Operationalization of Variables}

Sekaran (2000) defined that operationalizing a concept and to render it measurable, is done by looking at the behavioral dimensions, facets, or properties denoted by the concept. These are then translated into observable and measurable elements so as to form an index of measurement of the concept. Thus, the variables understudy were operationalized and presented in the following paragraphs.

\section{Independent Variables}

The independent variables of the study consists of seven factors in Quality Management Practices and are presented as follows:

Top Management Influence: The need for top management to initiate, lead and engage in quality initiatives is a significant factor in influencing the development of quality management in an organization. This construct was assessed using three related dimensions, namely: top management commitment, leadership for quality and strategic quality planning. This was evaluated using a questionnaire which had nineteen statements and the respondents expressed agreement or disagreement on a five-point Likert-type scale, anchored at the extremes from 1 as strongly disagree to 5 as strongly agree. The Cronbacha of 0.93 for the scale in the study indicated a high level of internal reliability. 
Customer Focus: This study adapted the instruments developed by Powell (1995) and Saraph et al. (1989). An eight-item instrument measured the extent to which an organization institutionalized this practice. The response format was a five-point Likert-type scale ranging from 1 for strongly disagree to indicate that the organization did not institutionalized this practice, to 5 strongly agree to indicate that the organization highly institutionalized the practice. The internal reliability of the scale assessed by Cronbach-a was 0.86 for this study.

\section{Employee Focus: This construct was concep-} tualized through three dimensions: employee empowerment, employee involvement, and employee rewards and recognition. An eighteen-item instrument was used to assess the construct. The response format was a five-point Likert-type scale ranging from 1 (strongly disagree) to 5 (strongly agree). The Cronbach-a of 0.91 obtained for the scale in the study indicated a high internal reliability.

Quality Training: This construct was operationalized in terms of training in quality principles, problem solving skills and group dynamic; as well as statistical techniques. A five-point Likert-type scale was used to measure the extent the organization institutionalized quality training, ranging from 1 (strongly disagree) indicating low concentration in quality training, to 5 (strongly agree) indicating high practice in quality training. The Cronbach-a of 0.77 for the scale in the study indicated an acceptable level of internal reliability.
Supplier Relationship: This construct was measured using a six-item instrument and was conceptualized in terms of relationship for quality and suppliers asking for higher quality standards. A five-point Likert-type scale was used to measure the extent of an organization established supplier relationship for quality superiority, ranging from 1 for strongly disagree to 5 indicating strongly disagree to the statements given. The Cronbach-a of 0.89 obtained for the scale in the study suggested that the measurement has a high internal reliability.

Information and Communication Technologies (ICT): In this globalized era, most world class organizations are building telecommunication networks and information systems to allow effective sharing of information and data bases among different part of organization as well as with customers, dealers and supplier. Accessibility to information flow is critical to TQM. This construct was measured using a nineitem instrument, ranging from 1 (strongly disagree), indicating low institutionalization of ICT, to 5 (strongly agree) showing high institutionalizing the ICT. The internal reliability of the scale assessed by Cronbach-a was 0.91 for this study.

Process Management: The dimensions of continuous process improvement, process quality assurance and quality measurement operationalized this construct. A fourteen-item instrument was used to measure the variable of process management. The response format was a five-point Likert-type scale ranging from 1 for strongly disagree to indicate that the organization did not institutionalize this practice, to 5 strongly agree to indicate that the organization 
highly institutionalized the practice. The Cronbach-a of 0.87 obtained for the scale in the study indicated a high internal reliability.

The average score of responses to various items of measurement to the dimensions were calculated, in order to obtain the score for the level of each of the seven-quality management practices under study.

Dependent Variable - Productivity in Revenue and Cost Management: This construct was measured using an eight-item instrument. A fivepoint Likert-type scale with the scheme ranging from 1 (strongly disagree), indicating low productivity in revenue and costmanagement, to 5 (strongly agree) for high productivity in revenue and cost management was used to measure this construct. The Cronbach-a of 0.89 obtained for the scale in the study indicated a high internal reliability.

In order to obtain the score for the level of productivity in cost management practices in the organizations under investigation, the average score of responses to various items of measurement to the dimension were calculated.

\section{RESULTS AND ANALYSIS}

This section presents the results of the study. The descriptivestatistics that include the means standard deviations, minimum and maximum scores for the variables in the study are reported in Table 1.

Table 1

Descriptive Statistics for the Variable in Study $(n=80)$
Mean S.D. Min. Max. Theoretical Range

$\begin{array}{lllll}3.86 & 0.56 & 2.40 & 5.00 & 1.00-5.00 \\ 3.79 & 0.68 & 2.29 & 5.00 & 1.00-5.00 \\ 3.45 & 0.62 & 1.60 & 5.00 & 1.00-5.00 \\ 3.39 & 0.72 & 1.40 & 5.00 & 1.00-5.00 \\ 3.55 & 0.72 & 2.00 & 5.00 & 1.00-5.00\end{array}$

$\begin{array}{lllll}3.37 & 0.66 & 2.00 & 5.00 & 1.00-5.00\end{array}$

$\begin{array}{lllll}3.32 & 0.73 & 1.53 & 5.00 & 1.00-5.00\end{array}$

$\begin{array}{lllll}3.56 & 0.71 & 2.00 & 5.00 & 1.00-5.00\end{array}$

Table2 presents the matrix for the Pearson Correlation test among the independent variables of the study. The results show that there exists significant correlation among the independent variables. The correlation coefficient ranges from $\underline{r}=0.39$ to $\underline{r}=0.75$, with $\underline{p}<0.0001$. Given this, the bivariate correlation betweenthe predictor variables is less than the cutoff of 0.8 , whereby a correlation of 0.80 or more is widely considered as an indicator of 
collinearity (Berry and Feldman, 1985). In this indicate the presence of severe respect, the variables in this study do not multicollinearity.

Table 2

Matrix Correlation between Independent Variables

\begin{tabular}{llllllll}
\hline Variables & TMI & CF & EF & QT & SR & ICT & PM \\
\hline TMI & \multirow{2}{*}{1.00} & $0.74^{*}$ & $0.75^{*}$ & $0.66^{*}$ & $0.49^{*}$ & $0.58^{*}$ & $0.57^{*}$ \\
CF & & 1.00 & $0.75^{*}$ & $0.67^{*}$ & $0.39^{*}$ & $0.61^{*}$ & $0.54^{*}$ \\
EF & & & 1.00 & 0.75 & $0.67^{*}$ & $0.72^{*}$ & 0.73 \\
QT & & & & 1.00 & 0.54 & 0.66 & 0.69 \\
SR & & & & & 1.00 & 0.69 & 0.57 \\
ICT & & & & & & 1.00 & 0.68 \\
PM & & & & & & & 1.00 \\
\hline
\end{tabular}

${ }^{*}$ Correlation is significant at the 0.01 level

In an attempt to identify which of the seven quality management practices have significant bearings on the level of productivity in revenue and cost management experienced by an organization, the study employed multiple regression analysis. This procedure explored the joint contribution of predictor variables, which may be different from the individual contribution obtained from simple bivariate calculation (Neter et al., 1990). Before proceeding with the regression analysis, the predictor variables were checked for the presence of multicollinearity. As observed in Table 2 , and the discussion above the presence of multicollinearity was not severe. However, a more rigorous and preferable test for diagnosing multicollinearity by examining the variance inflation factor (VIF) for each predictor was employed. Using a two-step collinearity diagnostics procedure in SPSS program as suggested by Hair et al. (1995) can further assess the problem of multicollinearity. The largest VIF (5.04) was well below the threshold (VIF =
10.0) as proposed by Neter et al. (1990) and Hair et al. (1995). Thus, this indicated that multicollinearity was not a potential problem. This notion was further supported when all conditional indices that exceed the threshold of 30 did not possess the proportion of coefficient variance for its associated variable which account for 0.90 or above for two or more coefficients (Hair et al., 1995). Thus, there was no support for the existence of severe multicollinearity.

The results of the regression analysis which was used to identify which of the quality management practices that had the significant account on the variability in the level of productivity in revenue and cost management in the local authorities under study is summarized in Table 3. It contains the standardized Beta and unstandardized coefficient $B$, standard error estimates and the t-test values and the significance for each variable in the regression. Table 3 also shows the coefficient of determination $\left(R^{2}\right)$ for the regression model, 
its F-test value, and the level of significance. Overall, analysis of the goodness and fit for the regression equation showed that the coefficient of determination, $R^{2}=0.18$, signifying that eighteen percent of the variation in the level of productivity in revenue and cost management was statistically explained by the regression equation.

Given the results in Table 3, the general expression in the form of regression equation can be stated as follows:

$$
\begin{aligned}
\mathrm{PRCM}= & 3.05+0.050 \mathrm{TMI}-0.228 \mathrm{CF}+ \\
& 0.565 \mathrm{EF}-0.125 \mathrm{QT}-0.093 \mathrm{SR}+ \\
& 0.39 \mathrm{ICT}-0.401 \mathrm{PM}+\varepsilon
\end{aligned}
$$

As Table 3 demonstrates, two of the predictor variables were found to be statistically associated significantly with the perceived level of productivity in revenue and cost management. The two variables were employee focus and process management. Thus, the results indicated that the perceived productivity in revenue and cost management was positively associated with employee focus, whereas the association with process management was negative. The results suggest that the local authorities that have high (low) institutionalization of employee focus will experience high (low) productivity in revenue and cost management. However, local authorities with high (low) process management experienced low (high) productivity in revenue and cost management. The first result supports previous research that quality management practices promote positive organizational performance such as financial performance and cost reduction, but the latter did not.

\section{Table 3}

Regression Results with Productivity in Revenue and Cost Management as Dependent Variable $(n=80)$

\begin{tabular}{lllccc}
\hline \multicolumn{1}{c}{ Variables } & Coefficient & Std Error & Beta & t-Test & Significance \\
\hline & 3.047 & 0.567 & & 5.377 & $0.000^{\mathrm{a}}$ \\
Intercept & $5.005 \mathrm{E}-02$ & 0.231 & 0.040 & 0.216 & 0.829 \\
Top Mgmt Influence (TMI) & -0.228 & 0.205 & -0.218 & -1.111 & 0.270 \\
Customer Focus (CF) & 0.565 & 0.280 & 0.495 & 2.019 & $0.047^{\mathrm{b}}$ \\
Employee Focus (EF) & -0.125 & 0.180 & -0.127 & -0.694 & 0.490 \\
Quality Training (QT) & $-9.321 \mathrm{E}-02$ & 0.168 & -0.094 & 0.554 & 0.581 \\
Supplier Relationship (SR) & 0.390 & 0.203 & 0.364 & 1.926 & 0.058 \\
ICT & 0.401 & 0.172 & -0.412 & 2.333 & $0.022^{\mathrm{b}}$ \\
Process Management (PM) & & & & &
\end{tabular}

$\mathrm{R}^{2}=0.139 ;$ Adjusted $\mathrm{R}^{2}=0.056 ;$ F-ratio $=1.665 ; \mathrm{p}<.05$

Level of Significance: a) $p<0.001 ; b) p<0.05$ 
The utility of results of this regression is in part dependent upon the violation of the assumption of regression analysis (Cohen and Cohen, 1983; Neter et al., 1990). In order to evaluate the homogeneity of variance of the residuals, the standardized residuals were plotted against the fitted dependent variable (efficiency in revenue and cost management). Given the absence of any systematic feature in the plot, there was no evidence to suggest that the assumption of homoscedasticity have been violated. The plots of the residuals against each predictor revealed that the data points all fall within a horizontal band of uniform width about a zero mid-point, suggesting that a linear relationship adequately represents the effect of each predictor. Finally, in order to test the normality of residuals, they were plotted against their normal scores. The normal probability plot suggested that there was no departure from normality, since the points in the plot appeared in a straight line. Furthermore, the histogram of standardized residuals revealed that the distribution does not depart dramatically from normal distribution.

\section{IMPLICATIONS}

The results identified two significant elements of quality management practices among local authorities in West Malaysia that have bearing on the perceived productivity in revenue and cost management. Employee focus has direct positive relationship with the productivity of revenue and cost management, whereas process management has negative or inverse relationship.
The results bear implications for the management of the local authorities. Quality management practices such as employee focus give positive organizational performance, specifically if the organization aims at improving the productivity in revenue and cost management. Giving due attention to employees such empowering them to encourage involvement and participation, practicing appropriate rewards and recognition system will improve employees' motivation as well as the level of organizational commitment. Consequently, the employees in turn portray their acceptance of organizational goals and their willingness to exert effort on behalf of the organization. The results of this exercise give rise to an increase in organization productivity, and thus improve productivity in revenue and costmanagement.

Given the positive outcome from the identified quality practices in the preceding paragraph, the management needs to address accordingly the process management practiced as the level of productivity in revenue and cost management has a negative relationship with this component. One possible explanation for this phenomenon is that since this practice involves the activities of continuous process improvement, process quality control and quality assessment, organizations are introducing a variety of quality assurance techniques into the system. Perhaps at this stage, management is obsessed by this exercise that excessiveresources are allocated and utilized which results in inefficient consumption of resources. Thus, overfocus on this component has induced dysfunctional behavior that results in producing inefficiency in revenue and cost management. This is what has been identified by Chang (1993) as 
the "Excessive Activity Syndrome"(EAS) of quality management.

\section{CONCLUSION}

The globalization and liberalization of world economic systems have greatly affected the performance of organizations. However, or- ganizations such as local authorities should perhaps proactively handle such demanding environment by inculcating prominent quality management practices. As the results of (1) this study have revealed, the management of - local authorities ought to give due attention to the process management that is practiced without neglecting the importance of employee focused elements in the context of addressing the productivity in revenue and cost management.

This study is subject to several limitations. First, the results should be interpreted within the usual limitations of survey research. Second, the results of this study were based on cross-sectional data, no statement of causation could be made. Third, participation in the survey was voluntary. It is possible that the respondents who declined to participated and/ or treated as drop-outs were different from those who participated.

Notwithstanding the limitations noted, the results of this study generally indicate that further understanding of the organizational performance such as productivity in revenue and cost management of local authorities can be addressed and further investigated to gain more knowledge of the role of quality management practices.

\section{BIBLIOGRAPY}

Alreck, P.L. \& Settle, R.B. (1995). The Survey Research Handbook ( $\left.2^{\text {nd }} e d.\right)$, Boston: Irwin.

Beechner, A.B. \& Koch, J.E. (1997). Integrating ISO 9001 and ISO 14001, Quality Progress, February, pp. 33-36.

Berry , W.D. \& Feldman, S. (1985). Multiple Regression in Practice, Sage University Paper 50, Beverly Hills, CA.

Chang, R.Y.(1993). Where TQM Goes, Training $\mathcal{E}$ Development, 47 (1): pp. 23-29.

Cohen, J. \& Cohen, P. (1983). Applied Multiple Regression/Correlational Analysis for the Behavioral Sciences ( $2^{\text {nd }}$ ed.), Hillsdale, NJ: Lawrence Erlbaum.

Donnelly, M.,Wisniewski, M., Dalrymple, J.F. \& Curry, A.C. (1995). Measuring Service Quality in Local Government: the Serqual Approach, International Journal of Public Sector Management, 8, pp. 15-20.

Feigenbaum, A.V. (1991). Total Quality Control ( $3^{\text {rd }}$ ed.), Baskerville: McGraw-Hill.

Flynn, B.B., Schroeder, R.G., \& Sakakibara, S. (1994). A Framework for quality management research and associated measurement instrument. Journal of Operation Management. 11(1), pp. 339-366.

Garvin, D.A. (1983). Quality On Line, Harvard Business Review, Sept/Oct.,pp. 65-75. 
Garvin, D.A. (1984). What Does Product Quality Really Mean? Sloan Management Review, 26, pp. 25-43.

Garvin, D.A. (1988). Managing Quality : The Strategic and Competitive Edge, New York: Free Press.

Hair,J.F., Anderson, R.E., Tatham, R.L. \& Black, W.C. (1995). Multivariate Data Analysis (4 ${ }^{\text {th }}$ ed.), Eaglewood Cliffs, New Jersey: Prentice Hall.

Kotler,P.(1994). Marketing Management Analysis, Planning, Implementation and Control,( $8^{\text {th }}$ ed.). New Jersey: Prentice Hall.

Ministry of Housing and Local Goverment (2000). Jabatan Kerajaan Tempatan. Kementerian Perumahan dan Kerajaan Tempatan. Web site: (http:// www.kpkt.gov.my).

Neter,J.,Wasserman,W.\&Kutner,M.H.(1990). Applied Linear Statistical Models ( $3^{\text {rd }}$ ed.), Homewood, IL.: Irwin.

Powell, T.C. (1995). Total quality management as competitive advantage : A Review and
Empirical Study. Strategic Management Journal. 16 (1), pp. 15-37.

Randall, L. \& Senior, M. (1994). A model for achieving quality in hospital hotel services. International Journal of Contemporary Hospital Management, 6(1/2): 68-74.

Raynor, M.E., (1992). Quality as a Strategic Weapon, Journal of Business Strategy, 13, pp. 3-9.

Ronen, B. \& Pass, S. (1994). Focussed Management: A business-oriented approach to total quality management. Industrial Management. May/June, pp. 9-12.

Saraph, J.V., Benson, G.P. , \& Schroeder, R.G. (1989). An Instrument for measuring the critical factors of quality management. Decision Sciences, Fall, 20: pp.810 -820.

Sekaran, U. (2000). Research Methods for Business : A Skill Building Approach ( $3^{\text {rd }}$ ed.), New York: John Wiley and Sons.

Walton, M. (1986). The Deming Management Method. New York: Pedigree. 